\title{
Acid and alkaline phosphatase localization in the digestive tract mucosa of the Hemisorubim platyrhynchos
}

\author{
Claudemir Kuhn Faccioli (Dr.) ${ }^{\mathrm{a}, \mathrm{b}, *}$, Renata Alari Chedid ${ }^{\mathrm{c}, \mathrm{d}}$, Ricardo Hideo Mori ${ }^{\mathrm{c}, \mathrm{d}}$, \\ Antônio Carlos do Amaral ${ }^{c}$, Irene Bastos Franceschini-Vicentini ${ }^{c}$, \\ Carlos Alberto Vicentini ${ }^{\mathrm{C}}$ \\ a Federal University of Uberlândia - UFU, Institute of Biomedical Sciences, 1720 Pará Avenue, 38.400-902, Uberlândia, MG, Brazil \\ b São Paulo State University - UNESP, Institute of Biosciences, Letter and Exact Sciences, 2265 Cristovão Colombo Street, 15054-000, São José do Rio Preto, \\ SP, Brazil \\ c São Paulo State University - UNESP, Department of Biological Sciences, Faculty of Sciences, 14-01 Engenheiro Luiz Edmundo Carrijo Coube Avenue, \\ 17033-360, Bauru, SP, Brazil \\ d São Paulo State University - UNESP, Aquaculture Center of UNESP - CAUNESP, Via de Acesso Prof. Paulo Donato Castellane, s/n, 14884-900 Jaboticabal, SP, \\ Brazil
}

\section{A R T I C L E I N F O}

\section{Article history:}

Received 21 March 2016

Received in revised form 14 July 2016

Accepted 3 August 2016

\section{Keywords:}

Ultrastructure

Cytochemistry

Epithelium

Teleost

Catfish

\begin{abstract}
A B S T R A C T
This cytochemical study investigated the acid and alkaline phosphatase of the digestive tract of Hemisorubim platyrhynchos. Acid phosphatase was detected in the lining epithelium throughout the digestive tract, whereas alkaline phosphatase was only observed in the intestine. In the esophagus, an acid phosphatase reaction occurred in the apical cytoplasm of the epithelial cells and was related to epithelial protection and freeing of superficial cells for sloughing. Similar results were also observed in epithelial cells of gastric epithelium. In the gastric glands, acid phosphatase occurred in lysosomes of the oxynticopeptic cells acting in the macromolecule degradation for use as an energy source, whereas in the vesiculotubular system, its presence could be related to secretion processes. Furthermore, acid phosphatase in the intestine occurred in microvilli and lysosomes of the enterocytes and was correlated to absorption and intracellular digestion. However, no difference was reported among the regions of the intestine. However, alkaline phosphatase reaction revealed a large number of reaction dots in the anterior intestine, with the number decreasing toward the posterior intestine. This enzyme has been related to several functions, highlighting its role in the nutrient absorption primarily in the anterior intestine but also being essential in $\mathrm{pH}$ regulation because this is a carnivorous species with many gastric glands with secretions that could damage the intestine.
\end{abstract}

(c) 2016 Elsevier GmbH. All rights reserved.

\section{Introduction}

The characterization and localization of the enzymes may help to elucidate the physiology of the organs of the digestive tract of fish and to resolve several nutritional and health problems in fish feeding. Several researchers have studied acid and alkaline phosphatase in fish digestive tract (Sastry, 1975; Chakravorty and Sinha,

\footnotetext{
* Corresponding author at: Institute of Biomedical Sciences, Federal University of Uberlândia - UFU, 1720 Pará Avenue, 38.400-902, Uberlândia, MG, Brazil.

E-mail address: claudemirkf@ufu.br (C.K. Faccioli).
}

1982; Harpaz and Uni, 1999; Arellano et al., 2001; Kozarić et al., 2004; Kuz'mina, 2008; Mir and Channa, 2010). Acid phosphatase in mucosa of the digestive tract could play a role in the freeing of superficial cells for sloughing (Hopwood et al., 1978) and in protection against harmful agents (Kent et al., 1966), as well as being correlated to the absorption and transport of metabolites (Mir and Channa, 2010), which serves as a marker of lysosomes (Kuz'mina, 2008). The absorption of nutrients by pinocytosis and subsequent intracellular digestion by the lysosomes enzymes in the enterocytes in fish has been discussed, and may be important to complement the luminal digestion (Govoni et al., 1986; Murray et al., 1996). 


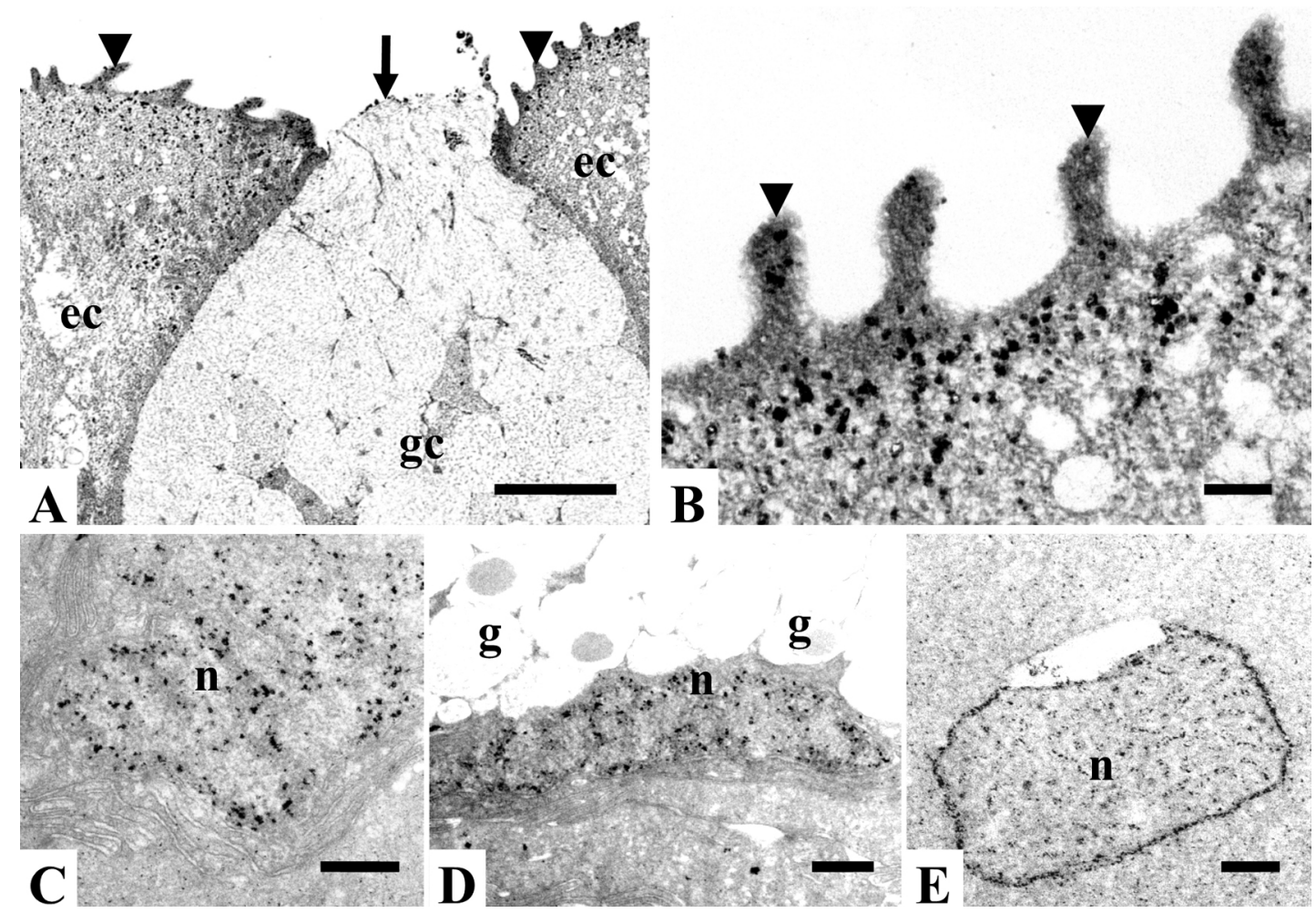

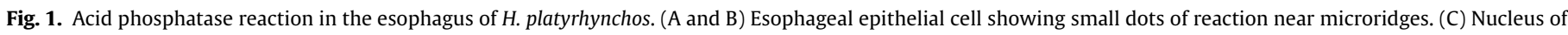

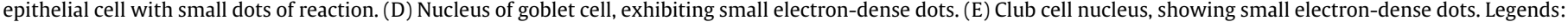
ec-epithelial cell; gc-goblet cell; $n$-nucleus; g-granules; arrow-opening of goblet cell; arrowhead-microridge. Bars: (A) $2 \mu$ m; (B) 200 nm; (C and D) 500 nm; (E) 200 nm.

Alkaline phosphatase is a widely distributed enzyme in different organs., Silva et al. (2010) reported that in fish intestine this is the predominant enzyme of the brush border of enterocytes, being expressed by active and mature enterocytes (ZamboninoInfante and Cahu, 2001). According to Harpaz and Uni (1999), the anterior region of the intestine in tilapia hybrids showed high activity levels of alkaline phosphatase, which was related with protein degradation. This enzyme is found in cell membranes where active transport takes place and plays a role in nutrient absorption (Roubaty and Portmann, 1988; Dupuis et al., 1991; Gawlicka et al., 1995; Moraes and Almeida, 2014). According to Lallès (2010), alkaline phosphatase acts as a regulator of fat absorption and also participates of regulation of surface $\mathrm{pH}$ and bicarbonate secretion. Further, Bates et al. (2007) showed that the intestinal alkaline phosphatase, located in the brush border of Danio rerio, could promote mucosal tolerance to resident gut bacteria. In this sense, Lallès (2010) concluded that alkaline phosphatase has a pivotal role in intestinal homeostasis.

The studied species belongs to the Pimelodidae family and Siluriformes order, which includes large catfishes and is distributed throughout Neotropical regions. Fishes of this family are highly appreciated for aquaculture because of the quality and flavor of their meat and the absence of intramuscular bones. Hemisorubim platyrhynchos, popularly called "jurupoca" in Brazil, is a migratory species with nocturnal carnivorous habit. The population size of this species has been reduced mainly due to building of hydroelectric dams that interrupt the migration flow required for reproduction (Bressan et al., 2009). Previous studies have described the morphology of the digestive tract of $H$. platyrhynchos (Faccioli et al., 2014, 2015). Thus, the current study analyzed the cytochemistry of the acid and alkaline phosphatase of the digestive tract of $H$. platyrhynchos to understand the morphophysiology of the carnivorous catfish digestive tract.

\section{Materials and methods}

\subsection{Animals}

The fishes of this study were obtained from Piraí Pisciculture in Terenos, MS Brazil. Fifteen adult specimens $(37.4 \pm 3.4 \mathrm{~cm}$ total body length) were fasted for one day to empty the digestive tract and were later anesthetized and euthanized with an overdose of benzocaine. Digestive tracts were dissected and fragments of the esophagus, stomach (cardiac, fundic and pyloric regions) and intestine (anterior, middle and posterior) were fixed in $1 \%$ glutaraldehyde in $0.1 \mathrm{M}$ sodium cacodylate buffer, $\mathrm{pH} 7.2$, for $1 \mathrm{~h}$, at $4{ }^{\circ} \mathrm{C}$ and they were intended for acid and alkaline phosphatase detection.

\subsection{Detection of acid phosphatase}

The fixed fragments of each organ were rinsed in $0.1 \mathrm{M}$ sodium cacodylate buffer, $\mathrm{pH} 7.2$, and then incubated at $37^{\circ} \mathrm{C}$ for $1 \mathrm{~h}$ in $25 \mathrm{mg}$ of cytidine-5'-monophosphate, $12 \mathrm{~mL}$ distilled water, $10 \mathrm{~mL}$ $0.05 \mathrm{M}$ acetate buffer (pH 5.0) and $3 \mathrm{~mL} 1 \%$ lead nitrate (Pino et al., 1981). After incubation, the samples were once again fixed in $2.5 \%$ glutaraldehyde, in $0.1 \mathrm{M}$ sodium cacodylate buffer, $\mathrm{pH} 7.2$; they were then post-fixed in $1 \%$ osmium tetroxide in the same buffer for $2 \mathrm{~h}$, in the dark. Samples were again rinsed several times in $0.1 \mathrm{M}$ sodium cacodylate buffer and block-stained with an aqueous solution of $2 \%$ uranyl acetate for $2 \mathrm{~h}$. Samples were then dehydrated in a graded acetone series and embedded in Araldite resin. Ultra-thin sections $(60-80 \mathrm{~nm})$ were mounted on copper grids and analyzed without post-staining. Controls were incubated in medium without substrate. The photodocumentation was performed with a Philips ${ }^{\circledR}$ CM100 transmission electron microscope (Netherlands). 



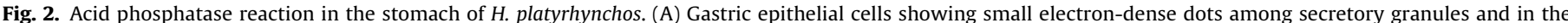

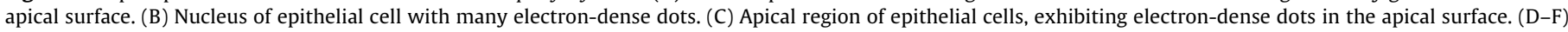

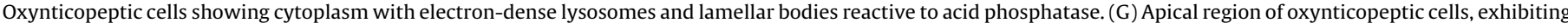

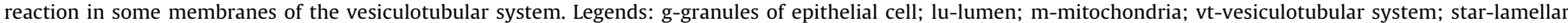

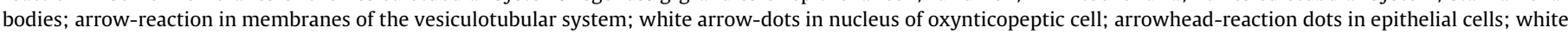
arrowhead-lysosomes in oxynticopeptic cell; asterisk-zymogene granule. Bars: (A) $2 \mu \mathrm{m}$; (B) $1 \mu \mathrm{m}$; (C) $500 \mathrm{~nm}$; (D) $2 \mu \mathrm{m}$; (E-G) $500 \mathrm{~nm}$.

\subsection{Detection of alkaline phosphatase}

The fixed fragments of each organ were rinsed in $1.4 \mathrm{~mL} 0.2 \mathrm{M}$ Tris-HCI buffer (pH 8.5), supplemented with $8 \%$ sucrose. The samples were later incubated at $37^{\circ} \mathrm{C}$ for $1 \mathrm{~h}$ in $0.2 \mathrm{M}$ Tris-HCI buffer (pH 8.5), $1 \mathrm{mM}$ ß-glycerophosphate, and $2 \mathrm{mM} \mathrm{CeCl}_{3}$ (Robinson and Karnovsky, 1983). After incubation, the samples were once again fixed in $2.5 \%$ glutaraldehyde, in $0.1 \mathrm{M}$ sodium cacodylate buffer, $\mathrm{pH} 7.2$ and then post-fixed in $1 \%$ osmium tetroxide, in the same buffer for $2 \mathrm{~h}$, in the dark. Afterwards, the samples were rinsed again several times in $0.1 \mathrm{M}$ sodium cacodylate buffer and block-stained with an aqueous solution of $2 \%$ uranyl acetate for $2 \mathrm{~h}$. Subsequently, they were dehydrated in a graded acetone series and embedded in Araldite resin. Ultra-thin sections $(60-80 \mathrm{~nm})$ were mounted on copper grids and analyzed without post-staining. Controls were incubated in medium without substrate. The photodocumentation was performed with a Philips ${ }^{\circledR}$ CM100 transmission electron microscope (Netherlands).

\subsection{Ethical note}

The current study was approved by the Committee for Ethics in Research of the Institute of Biosciences, Letters and Exact Sciences - UNESP, S. J. Rio Preto SP Brazil, by Protocol n. 075/2013. 


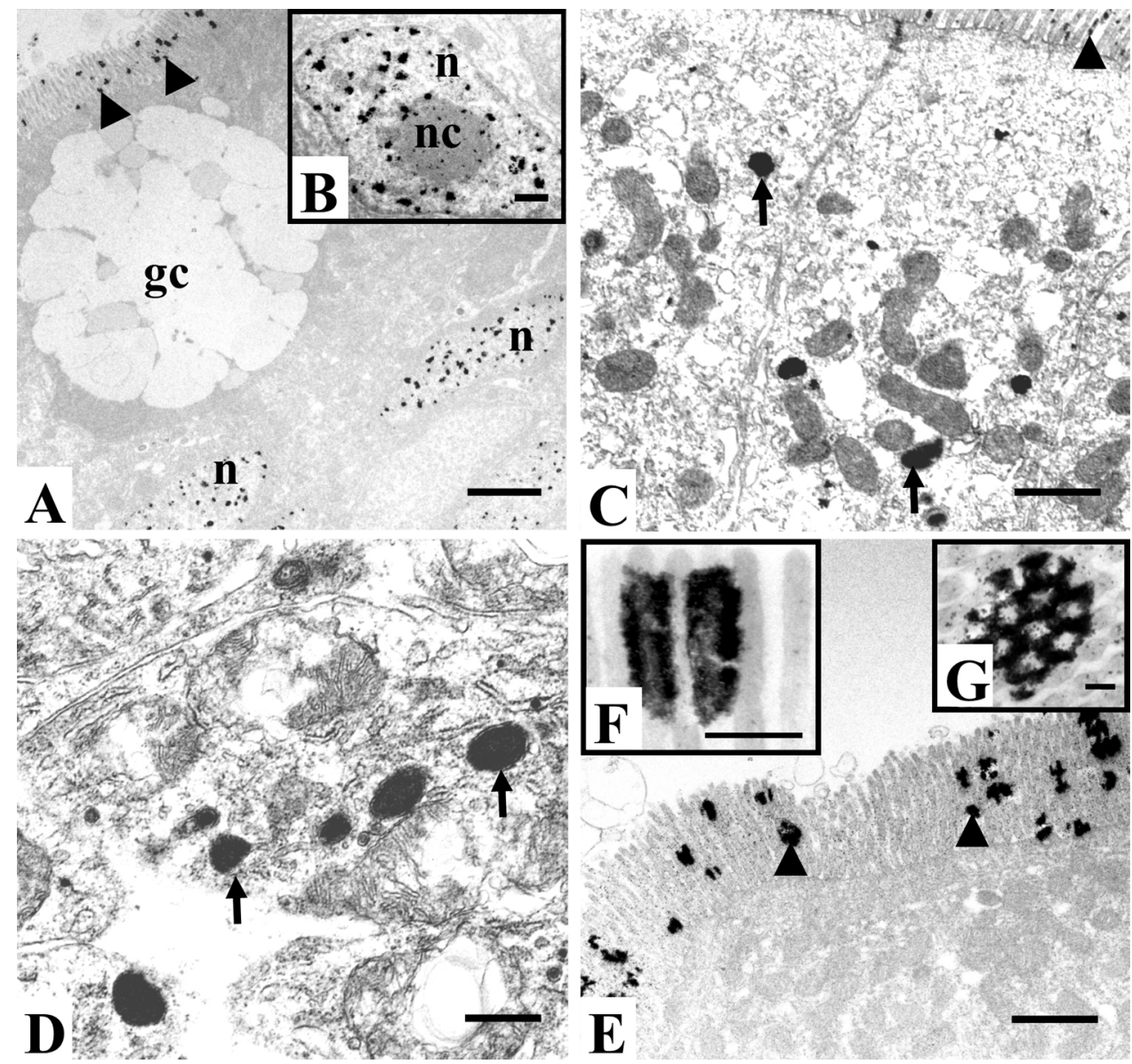

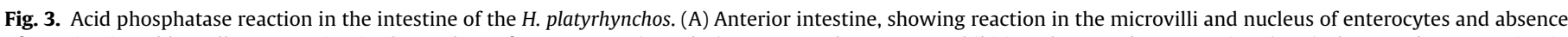

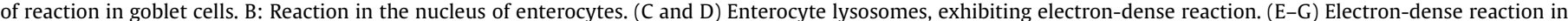

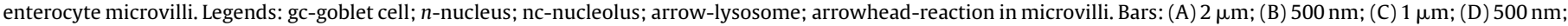
(E) $1 \mu \mathrm{m}$; (F) $250 \mathrm{~nm}$; (G) $100 \mathrm{~nm}$.

\section{Results}

Cytoenzymological reactions revealed that acid phosphatase was located throughout the epithelium lining the digestive tract of $H$. platyrhynchos, whereas alkaline phosphatase only occurred in the intestine. The esophageal mucosa was lined by stratified squamous epithelium composed of epithelial, goblet and club cells. The epithelial cells were distributed in all epithelium strata and they also formed a continuous apical layer of cells. In this apical layer, the epithelial cells showed acid phosphatase reaction in an apical cytoplasm, forming small electron-dense dots near microridges (Fig. 1A and B). The nucleus of the epithelial, goblet and club cells also reacted to acid phosphatase, with the reaction occurring more intensely in the epithelial and goblet cells (Fig. 1C-E). The cytoplasm of basal epithelial cells and the cytoplasm of goblet and club cells did not react to acid phosphatase.

The stomach of $H$. platyrhynchos was lined by simple columnar epithelium with gastric glands in the cardiac and fundic regions. Acid phosphatase reaction occurred in the gastric epithelial cells among the secretory granules and in the apical surface in contact with the plasma membrane, forming a continuous electron-dense reaction (Fig. 2A and C). Intense reaction to acid phosphatase was reported in the nucleus of epithelial cells (Fig. 2B). Acid phosphatase reaction also occurred in cytoplasm of oxynticopeptic cells of gastric glands in lysosomes and lamellar bodies (Fig. 2D-F). Moreover, the apical cytoplasm presented a vesiculotubular system with acid phosphatase reaction in some membranes (Fig. 2G). The nucleus of oxynticopeptic cells also reacted to acid phosphatase (Fig. 2F).

The intestine was lined by simple columnar epithelium with enterocyte and goblet cells. The goblet cell's cytoplasm did not react to acid or alkaline phosphatase. In enterocytes, the basal nucleus showed intense reaction to acid phosphatase (Fig. 3A and B). Cytoplasm enterocytes presented a few rounded electrondense vesicles reactive to this enzyme (Fig. 3C and D). Enterocyte microvilli also reacted to acid phosphatase (Fig. 3E-G). Although acid phosphatase reacts throughout the intestine, no variation in reaction intensity occurred among the different regions.

Alkaline phosphatase was only detected in the intestine. The most conspicuous localization of alkaline phosphatase reaction occurred in the enterocyte's microvilli (Fig. 4A-F). A large number of reaction dots were reported in microvilli of the anterior intestine, with the number decreasing towards the posterior intestine (Fig. 4A-F). The enterocyte's cytoplasm also showed small reaction dots. Acid and alkaline phosphatase reactions were not reported in the control groups (Fig. 4G).

\section{Discussion}

In this cytoenzymological study, acid phosphatase reaction was detected in the cytoplasm of esophageal and gastric epithelial cells, in the cytoplasm of oxynticopeptic cells, and in the microvilli and cytoplasm of enterocytes. Furthermore, acid phosphatase reaction also occurred in the nucleus of cells of the mucosa layer throughout 

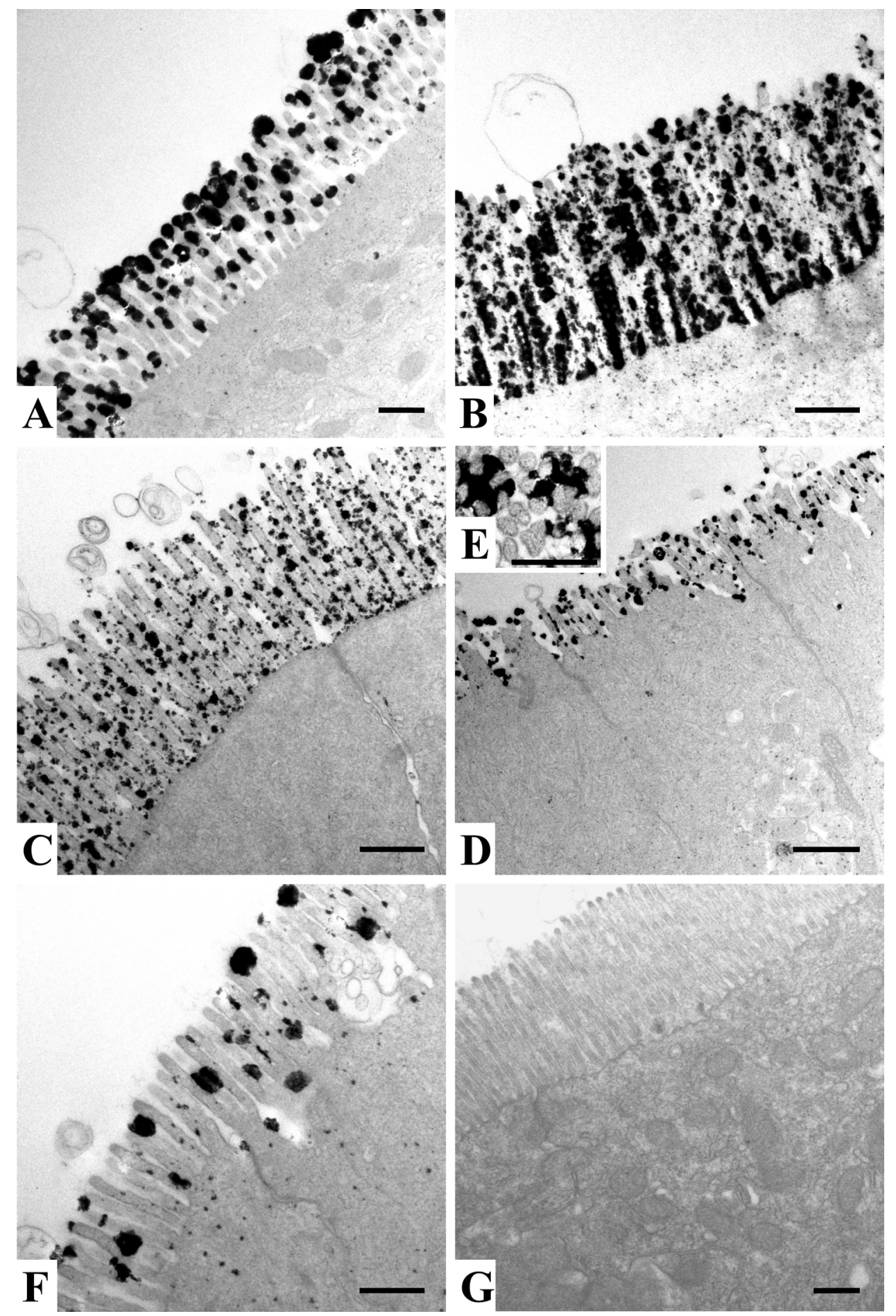

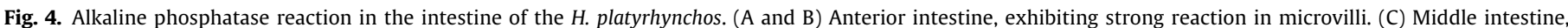

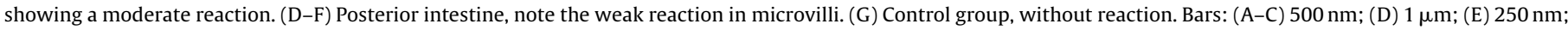
(F and G) $500 \mathrm{~nm}$.

the digestive tract, primarily in gastric epithelial cells, oxynticopeptic cells and enterocytes. Several researchers have reported the presence of nuclear acid phosphatase in fish (Calzada et al., 1998; Nóbrega and Quagio-Grassiotto, 2007; Guimarães and QuagioGrassiotto, 2008). According to Nóbrega and Quagio-Grassiotto (2007), acid phosphatase reaction in the nucleus of Leydig cells of Serrasalmus spilopleura was interpreted as a variation of the nuclear functional state. Consequently, acid phosphatase in the nucleus could activate or inhibit some key enzymes related to gene expression (Cruz Landim et al., 2002; Guirong et al., 2007).

The acid phosphatase enzyme has been reported in an esophagus of many fishes, such as Heteropneustes fossilis and Cirrhinus reba (Sastry, 1975), Catla catla (Chakravorty and Sinha, 1982), Perca fluviatilis (Hirji, 1983), Solea senegalensis (Arellano et al., 2001), and Merluccius merluccius (Kozarić et al., 2004). In H. platyrhynchos, this enzyme was located in the apical cytoplasm of epithelial cells. According to Faccioli et al. (2014), H. platyrhynchos is a carnivo- 
rous fish that swallow whole prey, which exposes the esophageal epithelium to constant abrasion. Therefore, the acid phosphatase observed in apical epithelial cells probably plays a role in epithelial protection and freeing of superficial cells for sloughing, as characterized to Hopwood et al. (1978) in studied human esophageal epithelium.

In the fish stomach, acid phosphatase was observed in the epithelial cells of Merluccius merluccius (Kozarić et al., 2004) and in mucosa and lamina propria-submucosa of Solea senegalensis (Arellano et al., 2001). According to Kent et al. (1966), acid phosphatase in the gastric mucosa was associated with the epithelial protection against harmful agents, suggesting that epithelial cells can protect the gastric mucosa of $H$. platyrhynchos, as well as could promote the sloughing process (Hopwood et al., 1978). In gastric glands of $H$. platyrhynchos, acid phosphatase was detected in lysosomes, lamellar bodies and the vesiculotubular system in the oxynticopeptic cells. Lysosomes are the cell's main digestive compartment to which all sorts of macromolecules are delivered for degradation (Lüllmann-Rauch, 2005), while the multilamellar bodies are residual bodies of phagosomes, which result from high metabolic activity of cells (Guimarães and Quagio-Grassiotto, 2008). However, Kozarić et al. (2004) correlated acid phosphatase in the gastric glands of Merluccius merluccius with the secretion process. In this sense, acid phosphatase in the vesiculotubular system of the oxynticopeptic cells of $H$. platyrhynchos can be involved in secretion process, while its presence in lysosomes and lamellar bodies probably indicates the degradation of macromolecules for use as an energy source.

Acid phosphatase was detected throughout the intestine of $H$. platyrhynchos. The wide distribution of acid phosphatase in the enterocytes may be correlated to the absorption and transport of metabolites in fish (Mir and Channa, 2010). According to Sosa et al. (1993), lysosome acid phosphatase is involved in internalization from the plasma membrane via the clathrin-coated pits, which justifies its localization in the microvilli of $H$. platyrhynchos. On the other hand, the presence of acid phosphatase in the lysosomes of enterocytes in the studied species could be associated with intracellular digestion. Several authors have suggested pinocytotic absorption and intracellular protein digestion mainly in posterior intestine as an alternative pathway of protein digestion in teleost (Rombout et al., 1985; Govoni et al., 1986; Murray et al., 1996). The current cytochemical study revealed no difference in the quantity or intensity of acid phosphatase among intestinal regions. According to Wilson and Castro (2010), the quantitative significance of pinocytotic protein uptake for the intracellular digestion is questionable and the most absorption in fishes occurs in the anterior intestine. In this sense, the present study showed a strong alkaline phosphatase reaction compared with acid phosphatase in the anterior intestine of $H$. platyrhynchos. Moyano et al. (1996) reported similar results in Sparus aurata larvae and suggested a greater significance of the intestinal absorption of macromolecules in relation to the pynocitic processes.

Alkaline phosphatase is an enzyme related to cell membranes where active transport takes place and acts in nutrient absorption (Roubaty and Portmann, 1988; Dupuis et al., 1991; Gawlicka et al., 1995; Lallès, 2010; Moraes and Almeida, 2014). Villanueva et al. (1997) concluded that an important function of alkaline phosphatase in the intestine of Cyprinus carpio was the dephosphorylation of nutritional compounds, this was especially apparent when the high amount of the enzyme in the first intestinal segment was taken into account. The present study revealed a large number of reaction dots to alkaline phosphatase in enterocyte's microvilli in the anterior intestine, with the number decreasing towards the posterior intestine of $H$. platyrhynchos. Similar results were observed in Heteropneustes fossilis (Sastry, 1975), Colisa fasciatus and Macrognathus aculeatus (Tyagi et al., 1980), Oreochromis niloticus (Smith et al., 2000), and hybrid tilapia (Hakim et al., 2006). According to Faccioli et al. (2014, 2015), the anterior intestine of $H$. platyrhynchos presents thick folds and long microvilli. In this sense, this cytoenzymological study corroborates the hypothesis that the anterior intestine of the studied species is the main site of absorption. Furthermore, intestinal alkaline phosphatase participates in regulation of surface $\mathrm{pH}$ and bicarbonate secretion (Lallès, 2010). Consequently, the strong alkaline phosphatase reaction in the anterior intestine of the $H$. platyrhynchos reveals the importance of this enzyme in epithelial protection because this organism is a carnivorous species with many gastric glands, the secretions of which could damage the intestine. According to Bates et al. (2007), intestinal alkaline phosphatase of Danio rerio could dephosphorylate and detoxify the endotoxin component of lipopolysaccharide of the gut microbiota, promoting mucosal tolerance to resident gut bacteria. Thus, alkaline phosphatase observed throughout the intestine of $H$. platyrhynchos is essential to functionality of this organ, having a pivotal role in intestinal homeostasis (Lallès, 2010).

\section{Acknowledgments}

The authors thank the Laboratory of Morphology Aquatic Organism (Faculty of Sciences/UNESP, Bauru) and the Electron Microscopy Center (Institute of Biosciences/UNESP, Botucatu) for their technical assistance. This research was supported by grants from Fundação de Amparo à Pesquisa do Estado de São PauloFAPESP, under protocol no. 2012/16143-2.

\section{References}

Arellano, J.M., Storch, V., Sarasquete, C., 2001. A histological and histochemical study of the oesophagus and oesogaster of the Senegal sole, Solea senegalensis. Eur. J. Histochem. 45, 279-294.

Bates, J.M., Akerlund, J., Mittge, E., Guillemin, K., 2007. Intestinal alkaline phosphatase detoxifies lipopolysaccharide and prevents inflammation in zebrafish in response to the gut microbiota. Cell Host Microbe 2, 371-382.

Bressan, P.M., Kierulff, M.C.M., Sugieda, A.M., 2009. Fauna ameaçada de extinção no estado de São Paulo: Vertebrados. Fundação Parque Zoológico de São Paulo: Secretaria do Meio Ambiente, São Paulo, p. 646.

Calzada, A., Medina, A., de Canales, M.L.G., 1998. Fine structure of the intestine development in cultured sea bream larvae. J. Fish Biol. 53, 340-365.

Chakravorty, P., Sinha, G.M., 1982. Detection and localization of alkaline and acid phosphatases in the digestive system of the adult Catla catla (Hamilton), an Indian freshwater major carp by histochemical methods. Gegenbaurs Morphol. Jahrb. 128, 799-808.

da Cruz Landim, C., Reginato, R.D., de Moraes, R.L.M.S., Cavalcante, V.M., 2002. Cell nucleus activity during post-embryonic development of Apis mellifera L. (Hymenoptera: Apidae). Intranuclear acid phosphatase. Genet. Mol. Res. 1, $131-138$.

Dupuis, Y., Tardivel, S., Porembska, Z., Fournier, P., 1991. Effect of some phosphatase inhibitors on intestinal calcium transfer. Int. J. Biochem. 23, 175-180.

Faccioli, C.K., Chedid, R.A., Amaral, A.C., Franceschini Vicentini, I.B., Vicentini, C.A 2014. Morphology and histochemistry of the digestive tract in carnivorous freshwater Hemisorubim platyrhynchos (Siluriformes: Pimelodidae). Micron 64, 10-19.

Faccioli, C.K., Chedid, R.A., Mori, R.H., Amaral, A.C., Franceschini Vicentini, I.B., Vicentini, C.A., 2015. Ultrastructure of the digestive tract in neotropical carnivorous catfish Hemisorubim platyrhynchos (Valenciennes, 1840) (Siluriformes, Pimelodidae). Scanning, http://dx.doi.org/10.1002/sca.21275.

Gawlicka, A., Teh, S.J., Hung, S.S.O., Hinton, D.E., de la Noüe, J., 1995. Histological and histochemical changes in the digestive tract of white sturgeon larvae during ontogeny. Fish Physiol. Biochem. 14, 357-371.

Govoni, J.J., Boehlert, G.W., Watanabe, Y., 1986. The physiology of digestion in fish larvae. Environ. Biol. Fish. 16, 59-77.

Guimarães, A.C.D., Quagio-Grassiotto, I., 2008. Cytochemical characterization of the endomembranous system during oocyte secondary growth in Serrasalmus spilopleura (Teleostei, Characiformes, Characidae). Acta Zool. 89, 37-46.

Guirong, L.I.U., Xianjiang, K., Mingshen, G.U.O., Wenjia, S.U.N., Qi, W., 2007. The study on the localization of acid phosphatase activity during spermiogenesis in chinese mitten-handed crab, Eriocheir sinensis. Bull. Mar. Sci. 9, 13-19.

Hakim, Y., Uni, Z., Hulata, G., Harpaz, S., 2006. Relationship between intestinal brush border enzymatic activity and growth rate in tilapias fed diets containing $30 \%$ or $48 \%$ protein. Aquaculture $257,420-428$.

Harpaz, S., Uni, Z., 1999. Activity of intestinal mucosal brush border membrane enzymes in relation to the feeding habits of three aquaculture fish species. Comp. Biochem. Physiol. A 124, 155-160. 
Hirji, K.N., 1983. Observations on the histology and histochemistry of the oesophagus of the perch, Perca fluviatilis L. J. Fish Biol. 22, 145-152.

Hopwood, D., Logan, K.R., Milne, G., 1978. The light and electron microscopic distribution of acid phosphatase activity in human normal oesophageal epithelium. Histochem. J. 10, 159-170.

Kent, T.H., Jervis, H.R., Kuhns, J.S.C., 1966. Enzyme histochemistry of acute staphylococcal enterotoxin gastroemteritis in rhesus monkeys. Am. J. Pathol. 48, 667-681.

Kozarić, Z., Kužir, S., Nejedli, S., Petrinec, Z., Sreboèan, E., 2004. Histochemical distribution of digestive enzymes in hake, Merluccius merluccius L. 1758. Vet. Arhiv 74, 299-308

Kuz'mina, V.V., 2008. Classical and modern concepts in fish digestion. In: Cyrino, J.E.P., Bureau, D.B., Kapoor, B.G. (Eds.), Feeding and Digestive Functions of Fishes. Science Publishers, pp. 85-154.

Lüllmann-Rauch, R., 2005. History and morphology of the lysosome. In: Saftig, P. (Ed.), Lysosomes. , first ed. Springer, pp. 1-16

Lallès, J.P., 2010. Intestinal alkaline phosphatase: multiple biological roles in maintenance of intestinal homeostasis and modulation by diet. Nutr. Rev. 68 323-332.

Mir, I.H., Channa, A., 2010. Histochemical distribution of lipase and acid phosphatase in the intestinal tract of the snow trout, Schizothorax curvifrons Heckel. J. Biol. Sci. 10, 643-647.

Moraes, G., Almeida, L.C., 2014. Nutrição e aspectos funcionais da digestão de peixes. In: Baldisserotto, B., Cyrino, J.E.P., Urbinati, E.C. (Eds.), Biologia e fisiologia de peixes neotropicais de agua doce. , first ed. Funep, UNESP, pp. 233-252.

Moyano, F.J., Díaz, M., Alarcón, F.J., Sarasquete, M.C., 1996. Characterization of digestive enzyme activity during larval development of gilthead seabream (Sparus aurata). Fish Physiol. Biochem. 15, 121-130.

Murray, H.M., Wright, G.M., Goff, G.P., 1996. A comparative histological and histochemical study of the post-gastric alimentary canal from three species of pleuronectid, the Atlantic halibut, the yellowtail flounder and the winter flounder. J. Fish Biol. 48, 187-206.

Nóbrega, R.H., Quagio-Grassiotto, I., 2007. Morphofunctional changes in Leydig cells throughout the continuous spermatogenesis of the freshwater teleost fish, Serrasalmus spilopleura (Characiformes, Characidae): an ultrastructural and enzyme study. Cell Tissue Res. 329, 339-349.
Pino, R.M., Pino, L.C., Bankston, P.W., 1981. The relationships between the Golgi apparatus, GERL, and lysosomes of the fetal rat liver Kupffer cells examined by ultrastructural phosphatase cytochemistry. J. Histochem. Cytochem. 29, 1061-1064.

Robinson, J.M., Karnovsky, M.J., 1983. Ultrastructural localization of several phosphatases with cerium. J. Histochem. Cytochem. 31, 1197-1208.

Rombout, J.H.W.M., Lamers, C.H.J., Helfrich, M.H., Dekker, A., Taverne-Thicle, J.J., 1985. Uptake and transport of intact macromolecules in the intestinal epithelium of carp (Cyprinus carpio L.) and the possible immunological implications. Cell Tissue Res. 239, 519-530.

Roubaty, C., Portmann, P., 1988. Relation between intestinal alkaline phosphatase activity and brush border membrane transport of inorganic phosphate D-glucose, and D-glucose-6-phosphate. Pflügers Arch. 412, 482-490.

Sastry, V.K., 1975. Alkaline and acid phosphatase in the digestive system of two teleost fishes. Anat. Anz. 137, 159-165.

Silva, F.C.P., Nicoli, J.R., Zambonino-Infante, J.L., Le Gall, M.M., Kaushik, S. Gatesoupe, F.J., 2010. Influence of partial substitution of dietary fish meal on the activity of digestive enzymes in the intestinal brush border membrane of gilthead sea bream, Sparus aurata and goldfish, Carassius auratus. Aquaculture 306, 233-237.

Smith, B.J., Smith, S.A., Tengjaroenkul, B., Lawrence, T.A., 2000. Gross morphology and topography of the adult intestinal tract of the tilapian fish, Oreochromis niloticus L. Cells Tissues Organs 166, 294-303.

Sosa, M.A., Schmidt, B., von Figura, K., Hille-Rehfeld, A., 1993. In vitro binding of plasma membrane-coated vesicles adaptators to the cytoplasmic domain of lysosomal acid phosphatase. J. Biol. Chem. 268, 12537-12543.

Tyagi, M.P., Dalela, R.C., Verma, S.R., 1980. Histochemical mapping of alkaline phosphatase in the digestive system of a few teleost fishes. Z. Mikrosk. Anat. Forsch. 94, 21-32.

Villanueva, J., Vanacore, R., Amthauer, R., 1997. Intestinal alkaline phosphatase of the fish Cyprinus carpio: regional distribution and membrane association. J. Exp. Zool. 279, 347-355.

Wilson, J.M., Castro, L.F.C., 2010. Morphological diversity of the gastrointestinal tract in fishes. In: Grosell, M., Farrell, A.P., Brauner, C.J. (Eds.), The Multifunctional Gut of Fish. , first ed. Elsevier, pp. 1-55.

Zambonino-Infante, J.L., Cahu, C.L., 2001. Ontogeny of the gastrointestinal tract of marine fish larvae. Comp. Biochem. Physiol. C 130, 477-487. 